This item was submitted to Loughborough's Research Repository by the author.

Items in Figshare are protected by copyright, with all rights reserved, unless otherwise indicated.

\title{
Evaluating the viability of establishing container-based sanitation in low- income settlements
}

\section{PLEASE CITE THE PUBLISHED VERSION}

https://doi.org/10.3362/1756-3488.18-00027

\section{PUBLISHER}

Practical Action Publishing

VERSION

VoR (Version of Record)

\section{PUBLISHER STATEMENT}

This work is made available according to the conditions of the Creative Commons Attribution-NonCommercialNoDerivatives 4.0 International (CC BY-NC-ND 4.0) licence. Full details of this licence are available at: https://creativecommons.org/licenses/by-nc-nd/4.0/

\section{LICENCE}

CC BY-NC-ND 4.0

\section{REPOSITORY RECORD}

Dewhurst, Richard, Claire Furlong, Sabitri Tripathi, M.R. Templeton, and Rebecca E. Scott. 2019. "Evaluating the Viability of Establishing Container-based Sanitation in Low-income Settlements". figshare. https://hdl.handle.net/2134/37200. 


\title{
Evaluating the viability of establishing container-based sanitation in low- income settlements
}

\author{
Richard N. Dewhurst, Claire Furlong, Sabitri Tripathi, \\ Michael R. Templeton, and Rebecca E. Scott
}

\begin{abstract}
Container-based sanitation (CBS) services operate in a number of low-income urban settlements across the globe, providing sanitation services where other on-site and off-site sanitation systems face logistical and environmental restrictions. The viability of each CBS service is influenced by a number of location-specific factors. Drawing on an initial review of existing CBS services, this paper identifies and evaluates these factors in relation to establishing CBS in a new service location. By applying a weighted scoring matrix to these factors, the potential viability of CBS services has been assessed for urban informal settlements in Kathmandu Valley, Nepal. The viability of CBS services in these settlements was found to be most influenced by the current availability of basic sanitation facilities, the unfamiliarity with paying for sanitation services, and the universally adopted practice of anal cleansing with water. The process and scoring matrix developed and subsequently applied in Nepal are recommended as part of the pre-feasibility stage assessment where a CBS service is being considered as a sanitation option in new locations.
\end{abstract}

Keywords: faecal sludge management, Nepal, informal settlements, peri-urban, urban sanitation

RAPID URBANIZATION IS PLACING INCREASING pressure on land availability and resources in many cities in low- and middle-income countries. By 2050, 66 per cent of the world's population is expected to live in an urban environment compared with 30 per cent in 1950 (UN Department of Economic and Social Affairs, 2014). Large, unplanned, high-density urban and peri-urban settlements are emerging rapidly, to an extent whereby a quarter of the world's urban population now live in slum conditions (UN-Habitat, 2016). With this increase in dense, informal urban and peri-urban settlements, providing safely managed sanitation facilities is a major

Richard Dewhurst, MSc (richard.dewhurst01@gmail.com) independent consultant, UK; Dr Claire Furlong (c.furlong@un-ihe.org) senior lecturer and researcher, IHE Delft Institute of Water Education, Netherlands; Sabitri Tripathi (sabitritripathi@yahoo.com) professor, Nepal Engineering College; Dr Michael Templeton (m.templeton@imperial.ac.uk) Reader in Public Health Engineering, Department of Civil and Environmental Engineering, Imperial College London; Rebecca Scott (r.e.scott@Lboro.ac.uk) lecturer in Public Health Engineering, Water Engineering and Development Centre (WEDC), Loughborough University, UK

(C) The authors. This open access article is published by Practical Action Publishing and distributed under a Creative Commons Attribution Non-commercial No-derivatives CC BY-NC-ND license http://creativecommons.org/licenses/by-nc-nd/4.0/ 
challenge for achieving Sustainable Development Goal target 6.2, which requires that adequate and equitable sanitation is provided for all by 2030 (UN, 2017).

Innovative solutions are therefore required, particularly where sewerage is not an option in low- and middle-income areas due to high capital costs, low levels of access to a reliable water supply, and the often narrow, irregular street layouts of the neighbourhoods (Isunju et al., 2011). With the ever-increasing prevalence of global water scarcity (Mekonnen and Hoekstra, 2016), and the consequent increase in the value of water, methods of sanitation that do not rely on piped water supplies have been forecast to become more widespread (Moe and Rheingans, 2006). In such urban environments, on-site sanitation options such as pit latrines are adopted, but poor access for emptying, low infiltration rates, and restricted space make such options increasingly inappropriate (Reade, 2016; Thye et al., 2011). Land tenure and ownership issues further complicate the situation, with residents unwilling to invest to improve sanitation facilities due to insecure tenure, and institutions fearing legitimizing informal settlements by providing services, leaving many residents with very few options (Scott et al., 2015).

Since 2011, seven organizations have emerged around the world whose specific aim is to provide those living in densely populated, informal, urban and peri-urban settlements in low- and middle-income countries with access to sanitation facilities in the form of a container-based sanitation (CBS) service (Table 1). CBS services contain human excreta throughout the sanitation service chain by capturing it in containers that are sealable and removable. Used containers are replaced by operators

Table 1 CBS organizations identified by the authors in 2017

\begin{tabular}{|c|c|c|c|c|c|}
\hline $\begin{array}{l}\text { Organization } \\
\text { name }\end{array}$ & $\begin{array}{l}\text { Operational } \\
\text { location }\end{array}$ & $\begin{array}{l}\text { Operating } \\
\text { since }\end{array}$ & $\begin{array}{l}\text { Level of } \\
\text { provision }\end{array}$ & End use products & Number of units \\
\hline Clean Team & $\begin{array}{l}\text { Kumasi, } \\
\text { Ghana }\end{array}$ & 2011 & Household & None & $\begin{array}{l}\text { >500 (Greenland } \\
\text { et al., 2016) }\end{array}$ \\
\hline Loowatt & $\begin{array}{l}\text { Antananarivo, } \\
\text { Madagascar }\end{array}$ & 2012 & Household & $\begin{array}{l}\text { Compost, } \\
\text { energy }\end{array}$ & $\begin{array}{l}\approx 100 \text { (Gardiner et al., } \\
2017 \text { ) }\end{array}$ \\
\hline \multirow[t]{2}{*}{ Sanergy } & \multirow[t]{2}{*}{ Nairobi, Kenya } & \multirow[t]{2}{*}{2011} & \multirow[t]{2}{*}{$\begin{array}{l}\text { Household/ } \\
\text { Public }\end{array}$} & \multirow{2}{*}{$\begin{array}{l}\text { Organic } \\
\text { fertilizer, energy, } \\
\text { animal feed }\end{array}$} & $\begin{array}{l}\approx 30 \text { households } \\
\text { (McSorley, 2017) }\end{array}$ \\
\hline & & & & & $\begin{array}{l}\approx 600 \text { public } \\
\text { (O'Keefe et al., 2015) }\end{array}$ \\
\hline $\begin{array}{l}\text { Sanitation } \\
\text { First }\end{array}$ & $\begin{array}{l}\text { Tamil Nadu, } \\
\text { India }\end{array}$ & 2016 & $\begin{array}{l}\text { Shared } \\
\text { family }\end{array}$ & Compost & $\begin{array}{l}\approx 100 \text { (Kirby-Garton, } \\
2017 \text { ) }\end{array}$ \\
\hline Sanivation & $\begin{array}{l}\text { Naivasha, } \\
\text { Kenya }\end{array}$ & 2015 & Household & $\begin{array}{l}\text { Charcoal } \\
\text { briquettes }\end{array}$ & $\approx 100^{1}$ \\
\hline SOIL & $\begin{array}{l}\text { Port-au-Prince/ } \\
\text { Cap Haitien, } \\
\text { Haiti }\end{array}$ & 2012 & Household & Compost & $>1,100^{2}$ \\
\hline X-Runner & Lima, Peru & 2011 & Household & Compost & $>750^{3}$ \\
\hline
\end{tabular}

Notes: ${ }^{1}$ E. Woods, CTO \& founder, Sanivation, interview, 22 May 2017

${ }^{2}$ S. Kramer, Executive Director, SOIL, interview, 22 May 2017

${ }^{3}$ I. Medem, Co-founder and Chairperson of the Board, X-Runner, interview, 10 July 2017 
with clean, empty containers, and full containers are transported to a treatment facility where the waste is either treated and disposed of, or processed into sellable products such as fertilizer, charcoal briquettes, animal feed, or energy (Tilmans et al., 2015). The market conditions favourable to providing a financially viable CBS service are known to be highly complex (Mikhael et al., 2017). However, many other aspects of CBS services need to be considered to determine the overall viability of CBS in any given context.

The objectives of this research were to identify the criteria required to assess the viability of establishing CBS services, through a review of the experiences of existing CBS organizations. These criteria were then divided into constituent factors which were evaluated to determine their relative level of influence in assessing the suitability of new locations for the implementation of a viable CBS service. This paper presents the first comprehensive analysis of the conditions required for CBS service viability, as applied to assess the potential of new CBS services, based on the research.

\section{Methods}

The research was conducted in 2017 by Loughborough University, in collaboration with Nepal Engineering College (NEC) and Imperial College London, and used a phased approach. Ethical approval for the research was issued by Loughborough University's Ethical Approvals (Human Participants) Sub-Committee at the School level (ref. no. 17/05-12). All participants were provided with an adult participation information sheet and completed an informed consent form before taking part.

Phase 1 identified the diverse range of factors that have impacted the viability of current CBS services. Due to the newness of this field, published literature on CBS services is limited, although some data was obtained from CBS organizations' websites and from grey literature. To obtain sufficient information and data, CBS organizations were interviewed (Table 1) to gain an understanding of the issues and challenges they have encountered during the development of their service models.

In Phase 2, these factors were categorized into criteria, which were subsequently used to assess the viability of a CBS service in four low-income urban settlements (known locally as squatter settlements) within Kathmandu Valley, Nepal. The locations were identified with the assistance of NEC to ensure that settlements with varying levels of permanence, scale, and legal status of residents were assessed.

\section{Phase 1: factors affecting existing CBS service models}

In addition to document review and interviews with the founders of seven CBS organizations (Table 1), additional interviews were conducted with organizations involved in the earlier development of CBS services, to gain deeper insights into the preceding development of this approach. These included Oxfam, Water \& Sanitation For The Urban Poor (WSUP), i-San Associates (i-San, 2018), and the recently formed CBS Alliance (CBSA, 2018). The 14 semi-structured interviews offered insights into the issues encountered during the development of CBS operations, the business models currently adopted, and the reasoning behind operational procedures. 
The seven CBS organizations, having developed independently of each other over time, have different service delivery models suited to their specific context. Models are influenced by the physical characteristics and cultural practices where they operate, and the challenges encountered as a result. The individual factors affecting the viability of these CBS service providers were found to be wide ranging, diverse, and context dependent (Dewhurst, 2017). These factors can be grouped into nine distinct criteria (Table 2), which the authors propose should each be considered when assessing the potential for a new CBS service prior to its development.

\section{Phase 2: assessing the viability of establishing CBS services in new locations}

The factors identified during Phase 1 (Table 2) were applied to the four selected urban squatter settlements in Kathmandu Valley (Table 3). These settlements are

Table 2 Factors influencing the success of CBS services

\begin{tabular}{|c|c|}
\hline Criteria & Influencing factors \\
\hline \multirow[t]{3}{*}{ Cultural } & Familiarity with the concept of paying for sanitation services. \\
\hline & $\begin{array}{l}\text { Acceptability of having a toilet located within the dwelling and handling } \\
\text { sealed containers of human excreta or human urine. }\end{array}$ \\
\hline & $\begin{array}{l}\text { Anal cleansing practices and preference of toilet usage type (i.e. squatting } \\
\text { or sitting). }\end{array}$ \\
\hline \multirow{3}{*}{$\begin{array}{l}\text { Existing } \\
\text { sanitation } \\
\text { facility and } \\
\text { usage practice }\end{array}$} & $\begin{array}{l}\text { Convenience/opening hours, cost, proximity, cleanliness, and security of } \\
\text { available public facilities. }\end{array}$ \\
\hline & $\begin{array}{l}\text { Availability, cleanliness, convenience, maintenance costs, and required } \\
\text { quantity of water for private household, on-plot, or communal/shared } \\
\text { sanitation facilities. }\end{array}$ \\
\hline & Availability/proximity of piped water supply or functional sewers. \\
\hline \multirow[t]{3}{*}{ Operational } & $\begin{array}{l}\text { Availability and proximity of required space and local acceptability for } \\
\text { establishing a waste transfer station or treatment facility, or existing facility } \\
\text { with sufficient capacity. }\end{array}$ \\
\hline & $\begin{array}{l}\text { Availability of suitable cover material for use within the toilet container } \\
\text { (e.g. sawdust), additional required inputs in the treatment process } \\
\text { (e.g. food waste or electricity), and workforce/waste collectors. }\end{array}$ \\
\hline & $\begin{array}{l}\text { Ease of identification of dwellings, communication with customers, and } \\
\text { collection/exchange of CBS containers. }\end{array}$ \\
\hline $\begin{array}{l}\text { Geographical } \\
\text { and geological }\end{array}$ & $\begin{array}{l}\text { Impact of the local topography, vulnerability to flooding, water table, } \\
\text { ground infiltration rates, ground conditions, surfacing materials, and impact } \\
\text { of existing sanitation practices on drinking water supplies. }\end{array}$ \\
\hline \multirow[t]{2}{*}{ Physical } & $\begin{array}{l}\text { Housing density, ease of access, vehicular restrictions, settlement shape, and } \\
\text { settlement size. }\end{array}$ \\
\hline & Proximity of settlements providing potential future customers. \\
\hline \multirow[t]{4}{*}{ Financial } & Current level of payment for sanitation services (e.g. pit emptying, public toilets). \\
\hline & Ability to pay for sanitation services. \\
\hline & $\begin{array}{l}\text { Ease of establishing a cost-effective method to collect customer tariffs } \\
\text { (e.g. mobile money). }\end{array}$ \\
\hline & Extent and density of potential customer base. \\
\hline
\end{tabular}


158 R.N. DEWHURST ET AL.

Table 2 Continued

\begin{tabular}{ll}
\hline Criteria & Influencing factors \\
\hline Accommodation & $\begin{array}{l}\text { Dwelling size, height, internal arrangement, and permanence. } \\
\text { Availability of outdoor space on-plot or within the settlement to establish } \\
\text { alternative improved sanitation facilities. } \\
\text { Land tenure or ownership status within the settlement. }\end{array}$ \\
$\begin{array}{l}\text { End-use } \\
\text { product }\end{array}$ & $\begin{array}{l}\text { Acceptability of the use of products created from human waste. } \\
\text { Enabling } \\
\text { environment }\end{array}$ \\
& $\begin{array}{l}\text { Level of support, cooperation, or assistance anticipated from local } \\
\text { municipality, organizations, or other institutional bodies to establish and } \\
\text { operate CBS service. }\end{array}$ \\
\hline
\end{tabular}

Table 3 Selected settlements and their characteristics

\begin{tabular}{|c|c|c|c|c|c|}
\hline $\begin{array}{l}\text { Settlement } \\
\text { name }\end{array}$ & Location & $\begin{array}{l}\text { Population } \\
\text { size }\end{array}$ & Age & Permanence & $\begin{array}{l}\text { Tenure/legal } \\
\text { status }\end{array}$ \\
\hline Balkhu & $\begin{array}{l}\text { Western bank } \\
\text { of the Bagmati } \\
\text { River }\end{array}$ & $\begin{array}{l}250 \text { dwellings } \\
\text { (estimated } \\
\text { by size and } \\
\text { density } \\
\text { during } \\
\text { transect walk) }\end{array}$ & $<10$ years & $\begin{array}{l}\text { Poorly established } \\
\text { dwellings } \\
\text { generally } \\
\text { constructed from } \\
\text { corrugated metal } \\
\text { sheeting. }\end{array}$ & Squatters. \\
\hline Manohara & $\begin{array}{l}\text { Eastern } \\
\text { bank of the } \\
\text { Manohara } \\
\text { River }\end{array}$ & $\begin{array}{l}\text { 2,500 people } \\
\text { (Lumanti, } \\
\text { 2008) and } \\
\text { the largest } \\
\text { individual } \\
\text { squatter } \\
\text { settlement in } \\
\text { Kathmandu } \\
\text { Valley }\end{array}$ & $>20$ years & $\begin{array}{l}\text { Well-established } \\
\text { dwellings } \\
\text { generally } \\
\text { constructed from } \\
\text { bricks/blocks and } \\
\text { corrugated metal } \\
\text { sheeting. }\end{array}$ & $\begin{array}{l}\text { No formal } \\
\text { land titles. } \\
\text { Residents } \\
\text { permitted } \\
\text { to remain as } \\
\text { location is } \\
\text { further from } \\
\text { the city centre. }\end{array}$ \\
\hline Sankhamul & $\begin{array}{l}\text { North-eastern } \\
\text { bank of the } \\
\text { Bagmati River }\end{array}$ & $\begin{array}{l}500 \text { people } \\
\text { (Lumanti, } \\
\text { 2008) }\end{array}$ & $>30$ years & $\begin{array}{l}\text { Very well- } \\
\text { established and } \\
\text { densely populated } \\
\text { dwellings } \\
\text { generally } \\
\text { constructed from } \\
\text { bricks/blocks. }\end{array}$ & $\begin{array}{l}\text { 'Legalized' } \\
\text { settlement } \\
\text { due to } \\
\text { location and } \\
\text { length of } \\
\text { occupation. }\end{array}$ \\
\hline Thapathali & $\begin{array}{l}\text { Northern bank } \\
\text { of the Bagmati } \\
\text { River }\end{array}$ & $\begin{array}{l}260 \text { dwellings } \\
\text { (Manandhar, } \\
\text { 2014) }\end{array}$ & $\begin{array}{l}>10 \text { years } \\
\text { (note: } \\
\text { settlement } \\
\text { previously } \\
\text { demolished } \\
\text { in } 2012 \\
\text { and re- } \\
\text { established) }\end{array}$ & $\begin{array}{l}\text { Poorly established } \\
\text { dwellings } \\
\text { generally } \\
\text { constructed from } \\
\text { bamboo frames } \\
\text { with plastic } \\
\text { sheeting and } \\
\text { corrugated metal } \\
\text { walls/roofs. }\end{array}$ & $\begin{array}{l}\text { Squatters } \\
\text { (note: location } \\
\text { earmarked by } \\
\text { government } \\
\text { for } \\
\text { development). }\end{array}$ \\
\hline
\end{tabular}


generally located adjacent to the major rivers where, due to the inherent flooding risk, the associated land value is low. The data obtained from the four settlements was analysed to ascertain how viable CBS services would be. It was recognized that no single settlement was of sufficient size to support a financially viable CBS service on its own (Mikhael et al., 2017); therefore, the data was collated and assessed collectively.

Transect walks undertaken in each settlement provided an initial assessment of characteristics that could impact on the technical viability of a CBS service, using a standard recording format adapted from Ross et al. (2016). These walks provided data to feed into assessing the physical, existing sanitation, operational, accommodation, and geographical/geological criteria in Table 2.

Twenty households were selected using a random walk method from the four settlements (i.e. five per settlement) to conduct household questionnaires. The head of the household was targeted, and the concept of CBS was first explained. The questionnaire was used to determine the household characteristics and relevant socio-economic information, current sanitation facilities within the household or community, and the level of satisfaction with those facilities, as this information, specific to the context of squatter settlements, was not available from census data. Further questions identified cultural or physical barriers to the viability of CBS services and the acceptability of using any end-products resulting from the service. Data obtained from the household questionnaires contributed to the assessment of the cultural, existing sanitation, financial, accommodation, and end-use product criteria in Table 2.

A focus group discussion (FGD) was undertaken in Balkhu settlement to determine the residents' views on CBS service potential within their community. The current sanitation practices and the potential demand for future sanitation improvements, including the option of CBS, were explored. The data obtained contributed to the assessment of the cultural, existing sanitation, physical, financial, accommodation, and end-use product criteria in Table 2 .

Nineteen interviews (unstructured and semi-structured) were held with staff of local ministries (including Kathmandu Metropolitan City and the Department of Water Supply \& Sewerage) and NGOs working in Kathmandu Valley with knowledge of sanitation developments in the city. These helped to identify the extent to which the CBS service concept and model may be received within the broader enabling environment for sanitation services. Data obtained from these interviews supported the assessment of the cultural, operational, financial, end-use, and enabling environment criteria in Table 2 .

\section{Data analysis}

Case study findings, in the form of emerging factors likely to influence the viability of CBS as a sanitation option, were analysed using a weighted scoring matrix applied to the criteria established during Phase 1. Using an approach similar to a standard risk assessment, the level of risk to CBS service viability was calculated for each factor.

The degree to which any factor would benefit or hinder potential viability of CBS implementation was determined by assessing the extent of its existence or absence within the study area. Each factor was scored between -3 and +3 depending on the 
extent to which it was found to be present. A score of -3 would therefore be applied to any factor which would be universally absent. Higher values, up to +3 , would then reflect increasingly beneficial levels of presence of any factor. Where it was not possible to assess a factor, or if a factor was not applicable, no numerical value was applied. For this study the scoring was carried out by one assessor, while it is recognized that having a second independent assessment would ensure a level of quality control and reproducibility of the results.

A relative weighting of 1,2 , or 3 (representing low, medium, or high) was subsequently applied to each initial score, to give a total weighted impact score of between -9 and +9 . The relative weighting was determined in each case from an understanding of the significance of each factor, as encountered by existing CBS operators and from observations made in the settlements studied. As a result, the impact of each factor on the viability of a CBS service is directly related to the context in which the assessment is made. A similar method has been used to undertake service delivery assessments of WASH services in which scaled scores are calculated to determine the degree to which faecal sludge management services are functioning at each stage of the sanitation service chain (Peal et al., 2014). Findings of the fieldwork were used to populate the weighted scoring matrix, to determine the potential viability of CBS services in the study settlements of Kathmandu Valley.

\section{Results and discussion}

The following sections present an analysis of the nine criteria and the factors influencing them (Table 2) together with an overall assessment of CBS service viability, drawing on findings from household questionnaires and FGDs held in the study settlements.

\section{Cultural criteria}

Having a population that is used to paying for sanitation services or shows a very strong inclination towards paying for a service was identified as one of the key factors in providing a sustainable and viable CBS service. Acceptability of paying for a sanitation service varied widely according to the degree of establishment of the settlement, and the resulting level and quality of sanitation provision. In the more permanent and established settlements, none of the respondents were prepared to pay for a sanitation service, as their existing facilities were self-identified as being of an acceptable standard. However, in Balkhu and Thapathali, where a lower standard of sanitation was self-identified, over 75 per cent of residents reported that they would be happy to pay for improved sanitation. This was explored further during the FGD where the potential payment for a CBS service was approximately 50 NPR $(\approx$ US\$0.50) per household per month. Despite this, the generally low level of acceptance of paying for a sanitation service encountered in the squatter settlements would potentially affect the viability of a CBS service operating in these communities.

Regarding the acceptability of locating a toilet within the home, 80 per cent of residents in the more established settlements were found to already have toilets 
located within their homes or in close proximity outside. The concept of locating a toilet in the home was found to be desirable to those residents using shared or communal facilities.

The level of acceptability to participants for handling containers of human urine or faeces was high, with 90 per cent of residents having no issues with the potential handling or carrying of containers filled with human waste. This would be an advantage to a CBS service provider collecting faeces only, as users would generally be willing to manage the urine themselves.

Residents 'squat' rather than 'sit' and practice anal cleansing with water. Any CBS system would need to account for the containment, collection, transport, and treatment of the wash water. An increase in the volume of material requiring safe management would significantly add to the costs, efficiency, and overall sustainability of the service.

Existing household-level CBS systems currently require users to sit rather than squat. Without the design of the toilet itself adapting to accommodate this preference, an impact on the uptake of CBS can be expected. No other religious or cultural traditions were identified during the study that would obviously affect the viability of a CBS service.

\section{Existing sanitation and usage criteria}

Residents of the study settlements reported that they never use public toilets. The general lack of public toilets within Kathmandu Valley as a whole, and an unfamiliarity with the concept of 'pay-as-you-go' public toilets is likely to impact on the willingness of residents to pay for a sanitation service; the only service reportedly ever paid for was that of emptying septic tanks and this was confirmed by a mere two residents. This further supports the findings of the cultural criteria and could present a barrier that would need to be overcome.

The high level of private or on-plot pour-flush sanitation facilities that discharge directly to the adjacent river identified in the more established settlements would affect the potential viability of CBS. The resulting level of satisfaction with the available facilities (approximately 65 per cent) would impact negatively on the amount that residents would potentially be prepared to pay for a sanitation service.

The water requirement for current sanitation systems was not found to be a major incentive for adopting a dry CBS toilet. The settlements are all located on riverbanks, where flushing water is plentiful throughout the year. The proximity of a piped water supply was also found to be inconsequential, due to the immediacy of the adjacent river to each settlement. The lack of a nearby available sewer system would have more impact on the viability of CBS if the dumping of faecal waste into the rivers was not such a widespread practice, and prevention was more enforced by the municipality. However, until this becomes socially unacceptable an alternative method of disposal of faecal waste will not be sought by the residents, especially if a cost is incurred.

\section{Operational criteria}

The squatter settlements are located within densely populated areas, restricting the potential to establish a local treatment facility. Therefore, any treatment facility 
would need to be located some distance from the settlements, affecting efficiency and viability of a CBS service given the very high levels of traffic within the city. With no existing faecal sludge treatment plant (HPCIDBC, 2011), CBS service providers would also need to treat the collected faecal sludge.

The widespread acceptability of handling filled containers of human urine and faeces, discussed in the cultural criterion, bodes well for recruiting a workforce to collect and manage CBS containers.

Only 10 per cent of households surveyed reported not owning a mobile phone. This offers an advantage in establishing a CBS service as it would facilitate communication with customers and bill payers, helping improve the efficiency of the service.

The ease with which dwellings could be identified varied significantly, depending upon the permanence of each settlement. Buildings in the more established locations are easily recognizable, whereas those in less well-established settlements are more likely to change their appearance frequently due to their construction from temporary materials. Dwellings that regularly change appearance are more difficult for CBS collection teams to identify to collect containers.

\section{Geographical criteria}

The frequency and severity of flooding were found to be concerns among all the settlements, particularly during the monsoon. Due to the riverside locations of the settlements, flooding requires the residents to temporarily relocate until the floodwater subsides. The existing latrines, which discharge through a pipe to the adjacent river, become operational as soon as the floods recede, so inundation of floodwater is therefore not considered a key driver in the promotion of a CBS service. The low infiltration rates and high water tables found in these riverbank locations would also not be a significant issue as latrines relying on direct infiltration (such as pit latrines) were not found to be utilized.

\section{Physical criteria}

The high density of populations observed in the settlements would provide a potentially dense customer base for a CBS operator. The lack of available space would also limit the potential to establish alternative sanitation facilities to CBS. However, the density of population in the settlements and pressure on available space has led to the construction of networks of narrow paths and passageways that restrict vehicle access and makes the collection of CBS containers difficult. Access into the settlements themselves is generally good, as they are all within densely populated urban areas and never far from a main road. The linear, riverside nature of the settlements would reduce the efficiency with which CBS containers could be collected compared with a more compact layout.

The number of squatter settlements in Kathmandu Valley is high, with over 40 recorded in 2008 (Lumanti, 2008), and this figure has steadily grown since this time (L. Joshi, Program Manager - Housing, Lumanti Support Group for Shelter, interview, 19 June 2017). However, the settlements are geographically 
spread across the entire city, with many of the individual communities being quite small; 80 per cent of the squatter settlements have less than 100 households (Lumanti, 2008). This wide dispersion of the settlements would increase the costs to a CBS service provider, as the collection process would involve significant travel time between small communities in which only a minimal number of customers might live.

\section{Financial criteria}

The current high level of satisfaction with the existing sanitation arrangements provides little incentive for residents to start paying for a sanitation service which would be a new concept and would require significant behaviour change for the vast majority of people. This would lead to a very low customer uptake in most of the settlements, particularly the more established ones. When this factor is combined with the disparate spread of the settlements across the city, the financial viability and potential for a sustainable CBS service would seem to be low. However, the high level of mobile phone ownership would allow the potential for cost-effective tariff collection from customers through the use of a mobile payment method (e.g. mobile money).

\section{Accommodation criteria}

The average number of rooms in a dwelling was found to be 3.25. This arrangement could increase the level of acceptability towards CBS toilets, compared with singleroomed dwellings, as there would be a room available in which to locate an inside toilet while maintaining a level of privacy from other users of the dwelling. In the study, 90 per cent of dwellings were also found to have sufficient space to locate a CBS toilet within the dwelling, with only 5 per cent of respondents having any issue with this concept. Due to the availability of space within the homes, the lack of outdoor space observed would be less of an issue.

The length of habitation of those questioned, and their land ownership/tenure status, would all promote the introduction of a CBS service. All the respondents had lived in their respective settlements for at least 5 years to over 30 years in Sankhamul (Table 3). This would be advantageous to a CBS service provider, as lower levels of transience support lower customer turnover. The universal tenure status of squatting across the settlements would also potentially be an incentive for CBS services, as other formal sanitation services are unlikely to be provided to residents of such communities.

\section{End-use product criteria}

The acceptability of purchasing either fuel (charcoal or biogas), created during the treatment process of faecal waste, or fruit and vegetables, grown using compost produced from collected faecal waste, was found to be over 90 per cent across all the settlements. Historically human faeces has been used as a form of fertilizer in Nepal (WaterAid Nepal, 2008), so the concept of reuse is not new. This high level of 
familiarity with the concept would allow a market for reuse products to be developed. Additionally, the main fuel identified in the study settlements is bottled gas (95 per cent of the household questionnaire respondents), so a market for biogas produced via faecal waste treatment may exist as biogas production is already undertaken on a large scale in Nepal (AEPC, 2017).

\section{Enabling environment criteria}

Government plans and investments to beautify the river corridor in Kathmandu through the Bagmati Action Plan include improving water quality with the installation of new sewers in certain communities, together with protecting and visually improving the Bagmati riverbank with parks and gardens (Manandhar, 2014). Riverbank improvements will involve the eviction, relocation, and resettlement of the squatter settlements, in their absence of land rights (UN-Habitat, 2018). As a result, the installation of any permanent sanitation infrastructure to serve these settlements is not a feasible option. The non-permanent, mobile nature of CBS facilities and services would make this an appropriate approach in these settlements. However, acting against this is any long-term prospect for CBS services. This is severely limited by both the impending evictions and the minimal, if any, level of support for such efforts likely coming from local authorities and institutions, who would fear appearing to legitimize the settlements.

\section{Assessing the overall viability of $C B S$ services in the squatter settlements}

The data collated in the above criteria was used to populate the scoring matrix that was developed to help determine the potential viability of CBS services in the settlements collectively. An example of one section of the matrix applied to the 'Existing sanitation and usage criteria' described above can be seen in Table 4.

As part of the full analysis covering all nine criteria, five factors were identified as having a maximum negative impact (weighted score of -9 ) while only one factor scored a maximum positive impact (weighted score of +9 ). Bringing these findings together, Table 5 highlights the key factors that may have significant positive or negative effects on the potential viability of CBS implementation within the squatter settlements of Kathmandu Valley.

Based on this analysis, it can be determined that the potential viability of CBS within the context of squatter settlements within Kathmandu Valley is more influenced by negative factors, and therefore not conducive to employing this service option.

This assessment process clearly highlights those factors that could significantly affect or prohibit the successful implementation of a CBS service in any context; factors scoring -9 would have to be addressed further. Likewise, any factors scoring +9 should be considered further in terms of their potential significance for enabling service viability. The method adopted allows a large range of factors to be assessed without reliance on significant time or resources, eliciting a clear representation of the main potential barriers or benefits to CBS service viability. 
Table 4 Extract from weighted scoring matrix

\begin{tabular}{|c|c|c|c|c|c|c|c|c|c|c|c|}
\hline \multirow{2}{*}{$\begin{array}{l}\text { Weighting/ } \\
\text { importance }\end{array}$} & \multirow{2}{*}{$\begin{array}{l}\text { Factor } \\
\text { description }\end{array}$} & \multicolumn{8}{|c|}{ Potential effect of factor } & \multirow{2}{*}{$\begin{array}{l}\text { Weighted } \\
\text { impact score }\end{array}$} & \multirow{2}{*}{$\begin{array}{l}\text { Comments/ } \\
\text { implications }\end{array}$} \\
\hline & & -3 & -2 & -1 & 0 & 1 & 2 & 3 & $n / a$ & & \\
\hline $\mathbf{L}$ & $\begin{array}{l}\text { Convenience/ } \\
\text { opening hours } \\
\text { of public } \\
\text { facilities }\end{array}$ & & & & & & $\checkmark$ & & & 2 & $\begin{array}{l}\text { Facilities closed } \\
\text { at night }\end{array}$ \\
\hline L & $\begin{array}{l}\text { Cost of using } \\
\text { existing } \\
\text { public } \\
\text { facilities }\end{array}$ & & & & $\checkmark$ & & & & & 0 & $\begin{array}{l}\text { Public facilities } \\
\text { not used }\end{array}$ \\
\hline $\mathbf{L}$ & $\begin{array}{l}\text { Proximity of } \\
\text { nearest public } \\
\text { facilities }\end{array}$ & & & & & & & $\checkmark$ & & 3 & $\begin{array}{l}\text { Very few } \\
\text { facilities } \\
\text { available }\end{array}$ \\
\hline $\mathbf{L}$ & $\begin{array}{l}\text { Cleanliness } \\
\text { and quality } \\
\text { of public } \\
\text { facilities }\end{array}$ & & & & & & & & $\checkmark$ & - & $\begin{array}{l}\text { Not assessed } \\
\text { Facilities not } \\
\text { used }\end{array}$ \\
\hline $\mathbf{L}$ & $\begin{array}{l}\text { Quantity } \\
\text { of water } \\
\text { required } \\
\text { for private } \\
\text { household } \\
\text { or on-plot } \\
\text { sanitation } \\
\text { facilities }\end{array}$ & & & & & $\checkmark$ & & & & 1 & $\begin{array}{l}\text { Low as generally } \\
\text { pour-flush } \\
\text { facilities utilized }\end{array}$ \\
\hline M & $\begin{array}{l}\text { Cleanliness } \\
\text { of private } \\
\text { household } \\
\text { or on-plot } \\
\text { sanitation } \\
\text { facilities }\end{array}$ & & $\checkmark$ & & & & & & & -4 & $\begin{array}{l}\text { Private facilities } \\
\text { generally clean }\end{array}$ \\
\hline M & $\begin{array}{l}\text { Convenience } \\
\text { of private } \\
\text { household } \\
\text { or on-plot } \\
\text { sanitation } \\
\text { facilities }\end{array}$ & & $\checkmark$ & & & & & & & -4 & $\begin{array}{l}\text { Close proximity } \\
\text { and high } \\
\text { prevalence }\end{array}$ \\
\hline M & $\begin{array}{l}\text { Maintenance } \\
\text { costs of } \\
\text { private } \\
\text { household } \\
\text { or on-plot } \\
\text { sanitation } \\
\text { facilities }\end{array}$ & $\checkmark$ & & & & & & & & -6 & $\begin{array}{l}\text { Very low } \\
\text { maintenance } \\
\text { costs due to } \\
\text { proximity of } \\
\text { river }\end{array}$ \\
\hline H & $\begin{array}{l}\text { Availability } \\
\text { of private } \\
\text { household } \\
\text { or on-plot } \\
\text { sanitation } \\
\text { facilities }\end{array}$ & $\checkmark$ & & & & & & & & -9 & $\begin{array}{l}\text { Very high } \\
\text { availability of } \\
\text { private facilities }\end{array}$ \\
\hline
\end{tabular}


Table 5 Main negative and positive factors resulting from case study analysis

\begin{tabular}{|c|c|c|}
\hline \multicolumn{3}{|c|}{ Negative factors } \\
\hline Criteria & Description & Implication \\
\hline Cultural & $\begin{array}{l}\text { Extent of payment for sanitation } \\
\text { services historically by residents of } \\
\text { community }\end{array}$ & $\begin{array}{l}\text { Very low familiarity with concept } \\
\text { of paying for sanitation, which } \\
\text { will affect potential paying } \\
\text { customer base }\end{array}$ \\
\hline Cultural & $\begin{array}{l}\text { Impact of anal cleansing practices on } \\
\text { CBS implementation }\end{array}$ & $\begin{array}{l}\text { Washing for anal cleansing practised } \\
\text { universally. Impact on running costs } \\
\text { of service and potential for use in } \\
\text { public toilet context }\end{array}$ \\
\hline $\begin{array}{l}\text { Existing } \\
\text { sanitation }\end{array}$ & $\begin{array}{l}\text { Availability of private household or } \\
\text { on-plot sanitation facilities }\end{array}$ & $\begin{array}{l}\text { High level of availability of private } \\
\text { facilities, therefore limited demand } \\
\text { for CBS service }\end{array}$ \\
\hline Operational & $\begin{array}{l}\text { Availability of required space locally } \\
\text { for treatment facility establishment }\end{array}$ & $\begin{array}{l}\text { Densely populated area. Very limited } \\
\text { scope for local establishment of } \\
\text { treatment facility }\end{array}$ \\
\hline Financial & $\begin{array}{l}\text { Acceptance of paying/current level } \\
\text { of payment (e.g. pit emptying, } \\
\text { public toilets, etc.) within the } \\
\text { community for sanitation services }\end{array}$ & $\begin{array}{l}\text { Current low level of acceptance } \\
\text { of paying for a sanitation service; } \\
\text { therefore, a cultural change would } \\
\text { be required for widespread adoption } \\
\text { of any scheme }\end{array}$ \\
\hline \multicolumn{3}{|c|}{ Positive factors } \\
\hline Criteria & Description & Implication \\
\hline Accommodation & $\begin{array}{l}\text { Impact of the average housing } \\
\text { size on the potential for CBS } \\
\text { implementation (e.g. number of } \\
\text { rooms, type of rooms, etc.) }\end{array}$ & $\begin{array}{l}\text { High level of acceptance of locating } \\
\text { a toilet within the home, with } \\
\text { average dwelling size of } 3.25 \text { rooms }\end{array}$ \\
\hline
\end{tabular}

\section{Implications for practitioners}

The weighted matrix method used to assess the criteria for viability of CBS services for the squatter settlements in Kathmandu Valley could be used to evaluate other potentially suitable areas for CBS implementation, provided that the assessor is sufficiently knowledgeable about the implications and consequences of the different factors to make a realistic assessment of CBS viability. The authors also recommend that this method be applied by sanitation specialists seeking to establish CBS services as a sanitation option for any area, to initially determine its potential suitability and viability.

The weighting for each factor was not cross-checked with key informants from within the CBS community or residents of the target settlements in Kathmandu Valley, due to the limited time available for the study. Future application of this approach would be strengthened by having the assigned factor weightings confirmed with CBS professionals and the proposed communities, as a final stage in determining the viability of CBS services. 


\section{Conclusions}

Container-based sanitation (CBS) services are becoming recognized as an appropriate sanitation option for high-density, informal, urban and peri-urban settlements, where the ability to provide more standard forms of improved sanitation (such as pit latrines or septic tanks) is not viable. This research has identified a comprehensive range of factors that can affect the viability of CBS services in a given location. To assess the appropriateness of a new location for the potential establishment of a CBS service, consideration should be given to these factors and how they influence the criteria for its viability. Based on the findings of this research, a CBS service would not be a viable option within the current contexts found in the low-income settlements of the Kathmandu Valley.

This paper has demonstrated that the process used to assess the prevalence and significance of the range of factors helps identify the potential for CBS viability. The authors therefore recommend that the process be applied at the pre-feasibility stage in any new situation where a CBS service is being considered as a sanitation option.

\section{Acknowledgement}

The authors would like to acknowledge the support provided by the residents of the selected communities, key informant interviewees in Kathmandu, field assistants, and the members of the global CBS community who all freely gave up their time to assist.

\section{About the authors}

Richard Dewhurst, MSc (richard.dewhurst01@gmail.com) is an independent consultant based in the UK

Dr Claire Furlong (c.furlong@un-ihe.org) is a senior lecturer and researcher in sanitation in the Environmental Engineering and Water Technology Department, IHE Delft Institute of Water Education, Netherlands

Sabitri Tripathi (sabitritripathi@yahoo.com) is a Professor in the Science and Humanities Department, Nepal Engineering College

Dr Michael Templeton (m.templeton@imperial.ac.uk) is Reader in Public Health Engineering in the Department of Civil and Environmental Engineering, Imperial College London

Rebecca Scott (r.e.scott@Lboro.ac.uk) is a lecturer in Public Health Engineering in the Water Engineering and Development Centre (WEDC), School of Architecture, Building and Civil Engineering, Loughborough University, UK

\section{References}

Alternative Energy Promotion Centre (AEPC) (2017) Home page [online] <http://www. aepc.gov.np/?option=renewable\&page $=$ subrenewable\&mid $=2 \&$ sub_id $=16 \&$ id $=3>$ [accessed 19 February 2019].

Container Based Sanitation Alliance (CBSA) (2018) Home page [online] <http://www.cbsa. global/\#/> [accessed 19 February 2019]. 
Dewhurst, R. (2017) The Required Conditions and Success Criteria for Container-based Sanitation Viability and the Potential for Implementation in Kathmandu, Nepal, MSc dissertation, Loughborough University, UK.

Gardiner, V., Costa, F., Andriamahavita, A. and Gardiner, P. (2017) 'Serviced household toilets, FSM and ICT in Antananarivo: lessons learned', in FSM4: 60-7 [online] <https://www.susana. org/_resources/documents/default/3-2744-7-1489140211.\%20et\%20alpdf> [accessed 19 February 2019].

Greenland, K., de-Witt Huberts, J., Wright, R., Hawkes, L., Ekor, C. and Biran, A. (2016) 'A crosssectional survey to assess household sanitation practices associated with uptake of "Clean Team" serviced home toilets in Kumasi, Ghana', Environment and Urbanization 28(2): 583-98 $<$ http://dx.doi.org/10.1177/0956247816647343>.

High Powered Committee for Integrated Development of the Bagmati Civilization (HPCIDBC) (2011) Status and Strategy for Faecal Sludge Management in the Kathmandu Valley [online], Kathmandu, Nepal: HPCIDBC <https://ocw.un-ihe.org/pluginfile.php/4124/mod_resource/ content/1/Status\%20and\%20Strategy\%20for\%20FSM\%20Kathmandu\%20Valley\%20\% 282011\%29.pdf> [accessed 19 February 2019].

Integrated Sanitation Solutions for Urban Development (i-San) (2018) Home page [online] $<$ http://www.i-san.co.uk/> [accessed 19 February 2019].

Isunju, J.B., Schwartz, K., Schouten, M.A., Johnson, W.P. and van Dijk, M.P. (2011) 'Socioeconomic aspects of improved sanitation in slums: a review', Public Health 125(6): 368-3 $<$ https://doi.org/10.1016/j.puhe.2011.03.008>.

Kirby-Garton, L. (2017) 'Inner City Sanitation: India', in SanCoP19: Container-Based Sanitation [online], Sanitation First <http://www.susana.org/_resources/documents/default/3-2797-71496410249.pdf> [accessed 19 February 2019].

Lumanti (2008) Status of Squatter Communities along Bagmati River and its Tributaries in Kathmandu Valley, Kathmandu, Nepal.

Manandhar, S. (2014) 'Evicted once, Nepali squatters living in the ruins of a razed river settlement fear a recurring nightmare', Global Press Journal [online] <https://globalpressjournal. com/asia/nepal/evicted-once-nepali-squatters-living-in-the-ruins-of-a-razed-river-settlementfear-a-recurring-nightmare/> [accessed 19 February 2019].

McSorley, B. (2017) 'Oxfam's experience in Container based sanitation - Nairobi, Kenya (2010-2017)' [online], London, UK: Oxfam <http://www.susana.org/_resources/documents/ default/3-2797-7-1496410214.pdf> [accessed 19 February 2019].

Mekonnen, M.M. and Hoekstra, A.Y. (2016) 'Four billion people facing severe water scarcity', Science Advances 2(2): e1500323 <http://dx.doi.org/10.1126/sciadv.1500323>.

Mikhael, G., Shepard, J. and Stevens, C. (2017) The World Can't Wait for Sewers: Advancing Container-based Sanitation Businesses as a Viable Answer to the Global Sanitation Crisis [online], London: WSUP <https://www.wsup.com/content/uploads/2017/08/Clean-Team-whitepaper. pdf> [accessed 19 February 2019].

Moe, C.L. and Rheingans, R.D. (2006) 'Global challenges in water, sanitation and health', Journal of Water and Health 4(S1): 41-57 <https://doi.org/10.2166/wh.2006.0043>.

O'Keefe, M., Lüthi, C., Tumwebaze, I.K. and Tobias, R. (2015) 'Opportunities and limits to market-driven sanitation services: evidence from urban informal settlements in East Africa', Environment and Urbanization 27(2): 421-40 <https://doi.org/10.1177/ 0956247815581758>. 
Peal, A., Evans, B., Blackett, I., Hawkins, P. and Heymans, C. (2014) 'Fecal sludge management (FSM): analytical tools for assessing FSM in cities', Journal of Water Sanitation and Hygiene for Development 4(3): 371-83 <https://doi.org/10.2166/washdev.2014.139>.

Reade, A. (2016) What Potential is there for Container Based Sanitation and the Social Enterprise in Urban Emergencies? [online], ELRHA <https://www.elrha.org/wp-content/uploads/2015/01/ Container-Based-Sanitation-document.pdf> [accessed 19 February 2019].

Ross, I., Scott, R.E., Mujica, A. and Smith, M.D. (2016) Fecal Sludge Management Tools: Data Collection Instruments [online], Washington, DC: World Bank <https://dspace.lboro. ac.uk/2134/23699> [accessed 19 February 2019].

Scott, P., Cotton, A. and Sohail, M. (2015) 'Using tenure to build a "sanitation cityscape": narrowing decisions for targeted sanitation interventions', Environment and Urbanization 27(2): 389-406 <https://doi.org/10.1177/0956247815569415> [accessed 19 February 2019].

Thye, Y.P., Templeton, M.R. and Ali, M. (2011) 'A critical review of technologies for pit latrine emptying in developing countries', Critical Reviews in Environmental Science and Technology 41(20): 1793-819 <https://doi.org/10.1080/10643389.2010.481593>.

Tilmans, S., Russel, K., Sklar, R., Page, L., Kramer, S. and Davis, J. (2015) 'Container-based sanitation: assessing costs and effectiveness of excreta management in Cap Haitien, Haiti', Environment and Urbanization 27(5): 89-104 <http://dx.doi.org/10.1177/0956247815572746>.

UN (2017) 'Goal 6: Ensure access to water and sanitation for all' [online] <http://www.un.org/ sustainabledevelopment/water-and-sanitation/> [accessed 19 February 2019].

UN Department of Economic and Social Affairs, Population Division (2014) World Urbanization Prospects: The 2014 Revision, Highlights [online] <https:/esa.un.org/unpd/wup/publications/ files/wup2014-highlights.pdf> [accessed 19 February 2019].

UN-Habitat (2016) Slums Almanac 2015-16: Tracking Improvement in the Lives of Slum Dwellers [online] <https://unhabitat.org/wp-content/uploads/2016/02-old/Slum Almanac 2015-2016_ EN.pdf> [accessed 19 February 2019].

UN-Habitat (2018) 'Bagmati Action Plan prepared with support of UN HABITAT', 25 August 2018 [online], Nepal <http://unhabitat.org.np/media-center/news/bagmati-action-planprepared-with-support-of-un-habitat/> [accessed 19 February 2019].

WaterAid Nepal (2008) Assessment of Urine-Diverting Ecosan Toilets in Nepal [online], Kathmandu: WaterAid Nepal <https://www.susana.org/en/knowledge-hub/resources-and-publications/ library/details/1600> [accessed 19 February 2019]. 